\title{
骨モデル当てはめによる MR画像からの手骨位置姿勢同定
}

\author{
宮田なつき*1 鴨 島 里 実*2 太田順*2
}

\section{Position Identification of Hand Bones from MR Images by Bone Model Registration}

\author{
Natsuki Miyata*1, Satomi Kamojima*2 and Jun Ota*2
}

\begin{abstract}
This paper proposes a system that practically identifies the position and orientation of hand bones from magnetic resonance (MR) volume images by registration of a bone model. Investigation of the link structure of a human hand requires the measurement of the relative movement of the bones by identifying each bone configuration among a large number of hand poses of the same subject. The proposed system aims to save total time in acquiring bone configuration with the same accuracy compared with the completely-manual segmentation. From one of the MR scanning data of different poses, a bone model is generated by manually segmenting the bone region. The initial configuration of the bone model is set interactively by an operator and the model is aligned in MR voxel data by minimizing the performance index. Experimental results show the validity of the proposed system in terms of accuracy and required time for data-processing.
\end{abstract}

Key Words: MR, Hand Bone, Registration, Medical Imaging

\section{1.は じめに}

昨今，計算機上に人間の手のモデルを構築し，CAD モデルと 組み合わせて製品の事前評価を行うことで，使いやすい製品の 設計に役立てようという試みが盛んになってきている。様々な サイズの手が操作する動きを計測し活用するためには，関節の 位置や回転軸の向きなど, 正確なリンク構造を求め, 計測した 動きを精度良く計算機上で再構成する必要がある。正確なりン ク構造は，いくつかの静止姿勢の医用画像からそれぞ抽出さ れた骨格の輪郭情報であるメッシュモデルを用い, 解剖学的に 妥当な骨座標系を設定することで求めることができる [1]，その 際, 治療目的ではないことから, 被爆の可能性のある CT（コ ンピュータ X 線体軸断層撮影) 画像ではなく MR (磁気共鳴断 層撮影) 画像を使用することが望ましい.

ここで, 手の MR 画像は 100 枚程度のスライス画像から成 り，次の三つの特徵がある。

（1）骨と皮䖉で似たような輝度值をとる場合があり，骨領域 内でも輝度值が一定でないため, 境界があいまいである

(Fig. 1).

（2）手全体を含む空間に対し各骨が小さいため，解像度が相対 的に低い.

原稿受付 2006 年 1 月 12 日

*1产業技術総合研究所デジタルヒューマン研究センター

*2 東京大学大学院丁学系研究科

${ }^{* 1}$ Digital Human Research Center, National Institute of Advanced Industrial Science and Technology

${ }^{* 2}$ Graduate School of Engineering. Tokyo University
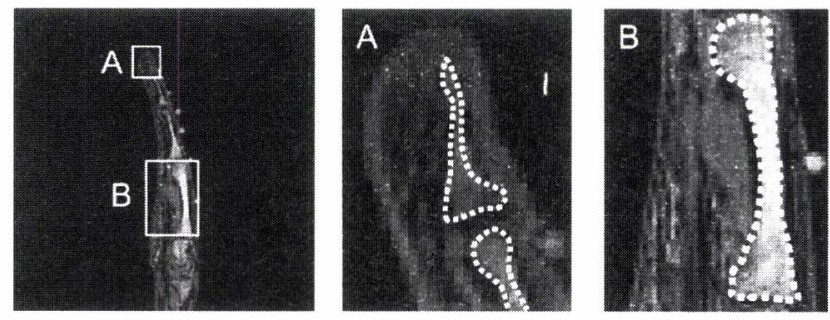

Fig. 1 An example of MR slice image of a hand with intensity variety: The bone region enclosed by white dotted curve sometimes appears with low intensity as skin (A) and sometimes with relatively high intensity (B)

（3）千根骨老除いても全 19 個と多数の骨が近接して存在して おり，姿勢によって計測空間内の位置姿勢が大きく变わり 計測方向との関係も変わるため, スライス画像への現机方 も様々である。

境界領域のあいまいさを解決するという観点からは, すべて の画像から手作業で骨領域を抽出し，メッシュモデルを作成す る方法が，最も現実的である [2]．しかし，この場合一つの姿勢 のデータを処理するのに, 熟練者でも最低 3 時間, 初心者では 1〜2 日在要し, 複数姿勢全体では才ペレータへの負担があまり に高くなってしまう。そのため，手作業の場合と精度を同等に 保ちながら省力化可能な代替システムが必要である。

関連する従来研究として, 同一被験者の異なる姿勢を計測し た画像データから骨のメッシュモデルの位置姿勢老求める手法 は, 大きく分けて 2 通りある。一つは, 可変形状モデルなどを 
宮田なつき鴨島

用い対象領域の輪郭を見つける手法 [3]〜 [9] だが，（1）の境界 の曖昧さから，境界を自動で判定することが難しい。また，二 次元にせよ三次元にせよ，求める骨格領域の完全内部に初期モ デルを設定しなけ机ばならないが，（3）の特徴により，やはり オペレータへの負担が高く, 現実的とはいえない.

もう一つは, 同一被験者の計測データの一つからその被験者 の骨のメッシュモデルを求めておき，これを，メッシュモデル の輪郭情報や作成元の MR 画像の輝度值情報を用いて他の計 測デー夕に当てはめ, それぞれの位置姿勢を求める方法である. 最初のモデルさえ作ってしまえば, 最終的な当てはめの部分の 計算は自動あるいは半自動で行われるため, 一般にオペレータ への負担が低くなり省力化向きの手法と言える. しかし, MR 画像に対するモデル当てはめ手法では単一の臓器を対象とした ものが多く，手骨を扱ったものは見当たらない，大腿骨を扱っ たもの[10] はあるが, 当てはめるモデルを作成した際の輝度值 分布の影響老強く受ける手法であるため，(2)，（3）の特徵を持 つ手骨のように, 解像度が低く, 計測する姿勢によって映りが 異なる場合，直接適用することは難しい，また，特徵（3）によ り,よく似た形状の骨がすぐ近くに存在するため, 当てはめプ ロ七スは局所解が多数あることを想定したうえで構成しなけれ ばならない.

そこで本研究では, 同一被験者の異なる複数资勢の MR 画像 から,すべて手作業で白く映った手骨領域を抽出して, その輪郭 を表すメッシュモデルを作成し，その位置姿勢を求める場合と 同等の精度を保ちながら，短時間で同じ情報を導出可能な省力 化システムの実装を目的とする。特徽（3）には，オペレータが およその初期位置を与えてから, モデル当てはめの最適化計算 を行うことで対応する．特徵 (1)，（2）には, 作成元の MR 画 像の輝度值情報を持たないメッシュモデルを骨モデルとし，モ デルの当てはめ計算の際の評価関数を工夫することで対応する.

以下，2 章ではモデル当てはめによる手骨位置姿勢同定手法 全体の概要を示し, 手作業抽出と同等とするための目標精度を 数值的に求める. 3 章ではモデル位置合わせに用いる評価関数 を検討する。 4 章では， 3 章で決定した評価関数を用い，提案シ ステム全体の有効性を議論する，5章で結論を述べる.

\section{2. 提案手法の概要と目標精度}

\section{1 手法の流れと実験に用いる MR 画像}

手骨の MR 画像では, 手骨と周辺の組織が同程度の輝度值 を持ち、また隣り合う骨との距離が非常に近い。そのため, 評 価関数の最適化計算によって正確な手骨位置姿勢存計算する際, 対象となる骨の領域から大きく外机た位置から探索を開始する と, 隣接する骨の影響を受けるため, 正確な位置姿勢への収束 を望めないことが予想される。そこで，オペレータがインタラ クティブに同定対象である骨の近くに骨モデルの初期位置姿勢 を設定することにする．作業全体は次のようになる。

・一つの姿勢の MR 画像から骨モデルを手作業で作成

・上記以外の姿勢の MR データそれぞれに対して

step1：オペレータによる扰拈よその初期位置設定

step2：評価関数の最適化による骨位置姿勢の自動計算

被験者の骨モデルは, 同一被験者の姿勢の異なる複数の三次
元 MR 画像のうち一つから作成する。具体的には，才ペレータ が約 100 枚のスライス画像それぞれから手作業で骨領域を抽出 したのち, マーチングキューブ法 [11] を用いて, 骨領域の輪郭 を表す三次元メッシュモデルを作成する [2].また，骨モデルの 初期位置姿勢は, 当てはめ先の三次元 MR 画像(ボクセルデー タ）をボリュームレンダリング [12]によって半透明な状態で可 視化したところに，骨モデル (メッシュモデル)を表示し，同 定対象骨と重なるようにその位置姿勢をインタラクティブに調 整することで決定する (Fig. 2). step2 については 3 章で詳し く説明する。

本論文の実験では，3名の健常な成人男性の MR 画像を用い た. MR 画像の撮像条件を Table 1 に, 撮像姿勢を Fig. 3 に 示す。ここでは, 一番左端の姿勢を基準姿勢として，その撮像 データから筩モデルを作成し，残り二つの姿勢の撮像データに おける各骨の位置姿勢を求めた。なお, 基準姿勢, 当てはめ先 姿勢ともに, 特に制約はない。また, 記述の簡単のため, 各骨 に参照番号 (bone No.) を振る (Fig. 4).

\section{2 骨位置姿勢の定義と同定結果の精度検証方法}

位置合わせ対象画像の座標系 $\left(\Sigma_{W}\right)$ における骨モデルの位置 姿勢を表す座標系 $\left(\Sigma_{\mathrm{B}}\right)$ は，骨モデルをすっぽり包み込む最小 の直方体である Oriented Bounding Box (OBB) [13] を用いて 定義する (Fig. 5). OBB の計算にはRAPID ライブラリ [14] を使用し，骨モデル座標系の原点は OBBの中心に，座標軸は $\mathrm{OBB}$ の各辺と平行に, 最も長い辺が $\mathrm{x}$ 軸に, 最も短い辺が $\mathrm{z}$ 軸に対応するよう設定する。

提案子法により同定さ机た結果の精度は, 同定対象とする MR
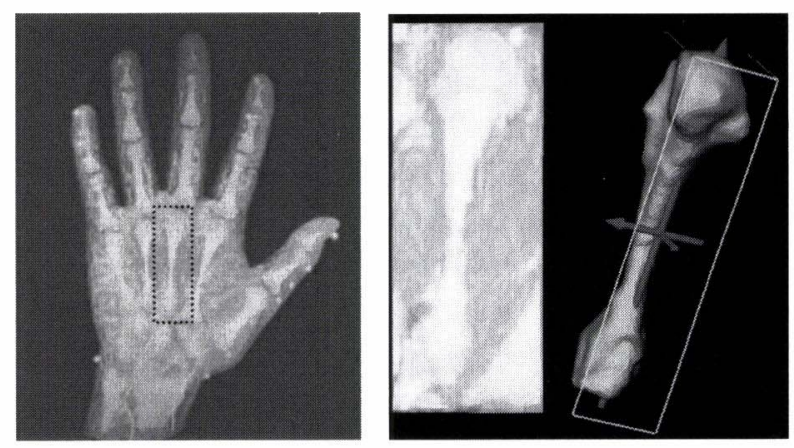

Fig. 2 A profile of interactive initial configuration settlement. A whole hand MR data drawn by volume rendering algorithm (left) is cropped for visibility in interactive settlement of bone model (right). Cropped volume corresponds to the region enclosed by the dotted square in the left

Table 1 MR imaging condition

\begin{tabular}{lr}
\hline Magnetic field strength & $1.0 \mathrm{~T}$ \\
Flip angle & $15[\mathrm{deg}]$. \\
FOV & $250[\mathrm{~mm}]$ \\
\hline \hline Size of MR images per 1 pose & $256 \times 256 \times 100[$ voxel $]$ \\
\hline Resolution of each slice image & $256 \times 256[$ pixel $]$ \\
Size of one pixel & $0.98 \times 0.98[\mathrm{~mm}]$ \\
Interval of the images & $1.5[\mathrm{~mm}]$ \\
Bit per pixel & $8[$ bits $/$ pixel $]$ \\
\hline
\end{tabular}




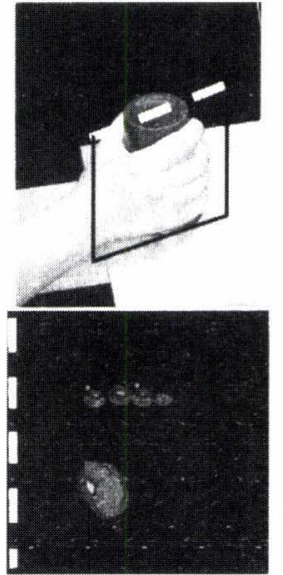

Base pose for bone model
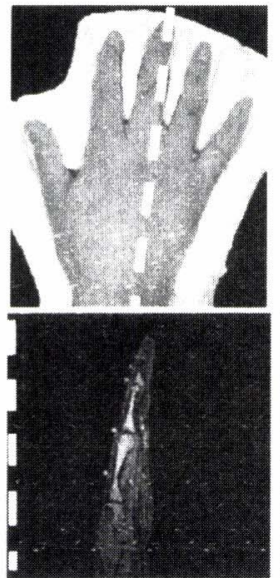

pose1
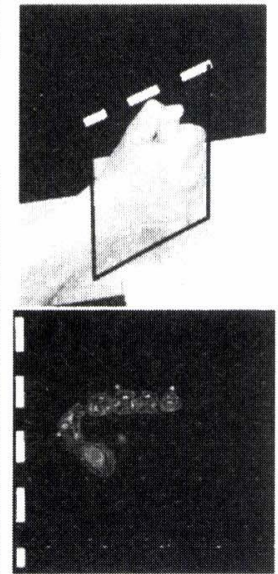

pose2
Fig. 3 MR images of three different poses: Dotted line in the upper row consistently corresponds to the dotted side of the slice image in the lower row

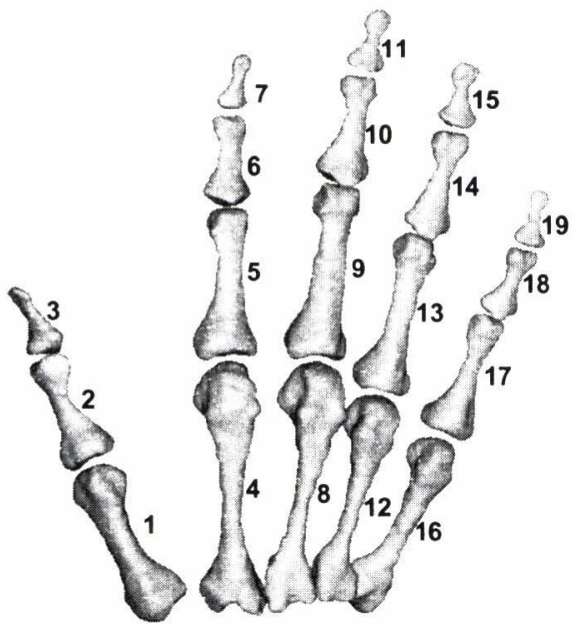

Fig. 4 Bone models with respective bone No.

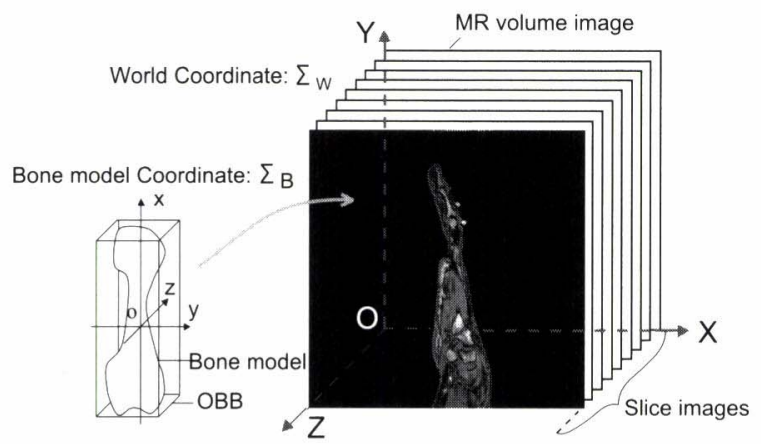

Fig. 5 The definition of coordinate system

画像から 1 名のオペレータが手作業で作成したメッシュモデル (目標モデルと呼ぶ）の位置姿勢からの䛊差で評価する。骨モ デルに定義された座標系を用いて精度評価を行うには，当ては め元の骨モデルと目標モデルにそれぞれ定義された座標系が互 いに矛盾しないことが前提となる。そこで, 目標モデルの位置
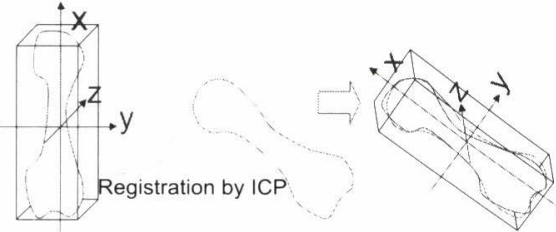

Bone model Target surface model (made from target MR image manually)

Fig. 6 The way to settle the coordinate system for the target bone mesh model in the different pose

Table 2 The data of bone models: the number of vertices and $\mathrm{OBB}$ size

\begin{tabular}{lcc}
\hline bone No. & number of vertices & OBB size $(\mathrm{x} \times \mathrm{y} \times \mathrm{z}[\mathrm{mm}])$ \\
\hline \hline 4 & 2800 & $69.4 \times 19.5 \times 19.5$ \\
\hline 5 & 1464 & $41.8 \times 17.6 \times 12.8$ \\
\hline 6 & 674 & $24.4 \times 14.1 \times 8.7$ \\
\hline 7 & 289 & $17.2 \times 10.0 \times 5.4$ \\
\hline
\end{tabular}

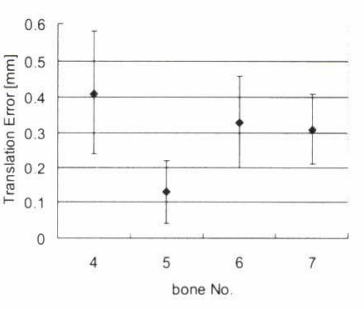

(a) Translation error

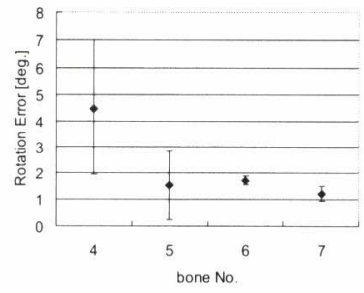

(b) Rotation error
Fig. 7 Differences among target models (mean \pm std. dev.)

姿勢を表す座標系は, 骨モデルを目標モデルに ICP (Iterative Closest Point）アルゴリズム [15] を用いて位置合わせし，その 位置に骨モデルの座標系をコピーすることで設定する（Fig.6). それぞれ独立にOBB を用いて座標系を定義するのではなくわ ざわざ上記のような手順を踏むのは，同一被験者の同じ骨であっ ても，異なる撮像デー夕では映りが異なり，形状にも違いが生 じるために，形状に大きく影響されるOBB ベースの座標系定 義方法では，「座標系が互いに矛盾しない」という前述の前提条 件が満たさ机ないからである。

メッシュモデル同士の位置姿勢のずれを定量的に評価するた めに，「平行移動ずれ量」と「回転ずれ量」の二つの評価指標を 設ける。前者は二つの座標系の原点間の距離，後者は二つの座 標系を一致させる最小弧の回転角度である。

\section{3 目標精度}

同定された結果の精度検証に用いられる目標モデルは，手作 業領域抽出を介して作成されたメッシュモデルであるため，才ぺ レータによって形状が若干異なり，OBBを用いて定義される位 置姿勢にはそもそもばらつきが伴う。同定された骨モデルの位 置姿勢の，目標モデルからの䛊差が，このばらつきの範囲内に 収まれば，同定された結果は手作業による方法と同等と言える。

そこで, 被験者 $\mathrm{A}$ の基準姿勢の MR 画像から 3 人のオペレー 夕がそれぞれ手作業で作成した第二指の中手骨，基節骨，中節 骨，末節骨 (bone No.4〜 7, Table 2) の目標モデルを用いて, オペレータによる目標モデルの位置姿勢のばらつきを求めた.

一つの目標モデルを基準とし，他の二つの目標モデルの基準 


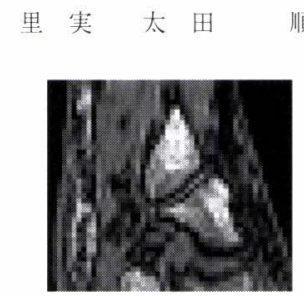

\section{3. 評価関数の検討}

\section{1 評価指標}

骨モデルの初期位置姿勢を設定（step1）したのち, 同定対象 である骨の正確な位置姿勢を, 評価関数を最小化することで求 める (step2). 二つの画像の位置合わせに従来よく用いられて きたのは,「類似度関数」と呼ばれる輝度值分布の一致度を指標 とする関数である，画像の撮像手段, 対象物体, 二つの画像の 撮像手段は同一か否かといった条件の組み合わせごとに, 様々 に提案されているが $[17]$ ～[19], 二つの画像の撮像手段が同じで ある本研究においては, 以下二つの指標の適用が考えられる。

・輝度差の総和 (SAD：Sum of Absolute Difference)

- 正規化相互相関 (NCC : Normalized Cross-Correlation) 両者とも二つの画像が比較的似ている場合に用いられるが，特 に SAD は対象物領域内の各画素の輝度值が平均的に同程度の 場合に, NCC は異なる場合に適用される。

類似度関数を用いる場合, 二つの画像に打いて, 対象物領域 内に含まれる各画素の輝度值が相対的に同様に分布することが 前提となる.しかし, 本研究で扱う手骨では, 骨の大きさに対 してMR 画像の解像度が低いため, 異なる姿勢の画像では同一 被験者の同一の骨であっても輝度值の分布の一致度が低い。そ の場合, 当てはめ元と当てはめ先の両者の情報を用いて計算さ れる指標は信頼性が低く, 対象画像における骨領域の輝度值情 報のみを用いた，より単純な指標の方が有効であると考えられ る。そこで, 骨モデルの内部に輝度值の高い領域をなるべく多 く含むという新しい指標

- 対象画像におけるモデル内部の輝度值和（SI：Sum of Intensity)

を提案する。これは骨の詳細な構造と輝度值の関倸に基づいた 指標となっている. 本研究で “手骨領域” とみなしているのは, 正確には, 脂肪分が多いために白く（輝度值が高く）写る海綿 骨層であり, そのすぐ外側には, 脂肪分が少ないために黒く(輝 度值が低く）写る薄い皮膜骨層が存在する（Fig. 8)。したがっ て指標 SI は, 対象骨のごく近傍に関しては, 正しい位置姿勢で もっとも高い值をとり，少しずれると輝度值の低い領域が含ま れて悪化することになり，この指標が改善するよう探索するこ とで正しい位置姿勢の計算ができる。

SI を用いることで, SADやNCC を使用した場合に比べ収 束結果の改善が期待できるのは, 例えば次のような場合である. まず，評価指標 SADを用いると誤った収束結果になる具体的 な状況の例を, 簡単のため二次元的な模式図を使って示すと, Fig. 9 (a)の上うな輝度值の分布状態が考えられる.これは, 当 てはめ対象の MR 画像デー夕としては, 該当骨領域の外側の本 来は非常に暗いはずの部分に, 明るい領域が少し膨張して映っ ており，当てはめ元の骨モデル内の方に，一部，膨張部分と同 じ輝度值が含まれているという状況である。このような MR 画 像に対し, 右方に初期值を設定し, 評洒指標 SADを使用して 当てはめ収束計算を行うと, 膨張部分に引きずられた収束結果

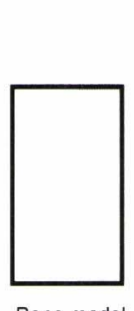

Bone model
となる。 果となる。

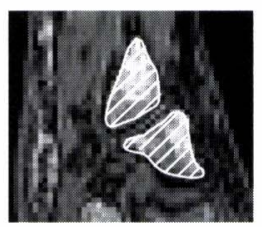

(b) Cancellous bone

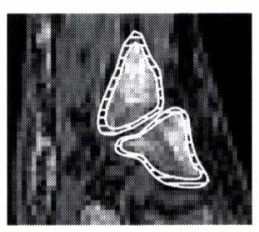

(c) Cortical bone

Fig. 8 An Example of distribution of intensity in MR image: Cancellous bone regions have high intensity and Cortical bone regions have low intensity

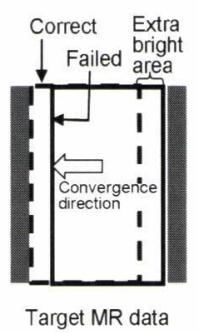

(a) Intensity pattern for SAD failure

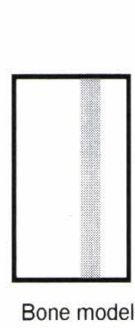

(b) Intensity pattern for NCC failure

Fig. 9 Examples of intensity pattern in convergence failure: density of grayscale corresponds to the intensity

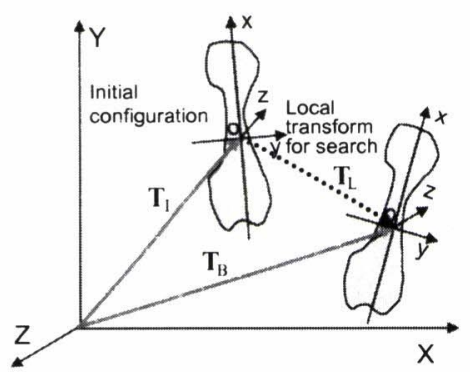

Fig. 10 Transform matrix: $\mathbf{T}_{\mathbf{I}}, \mathbf{T}_{\mathrm{L}}$, and $\mathbf{T}_{\mathrm{B}}$

同様に，評価指標 NCC を用いると誤った収束結果になる状 況としては, Fig. 9 (b) のような輝度值の分布状態が考えられ る.これは, 当てはめ対象の MR 画像としては, 該当する骨領 域の内部とその外側の軟部組織が同程度の輝度值で写っており, 当てはめ元の骨モデル内に，一部輝度值の低い部分が含まれて いるという状況である。このような MR 画像に対し，右方に初 期值を設定し, 評価指標 NCC を使用して当てはめ収束計算を 行うと, 該当骨領域のすぐ右の暗い部分に引きずられた収束結

どちらの分布状態でも，評価指標 SIを使用した場合は単純 に輝度值の総和の高いところを探索するため, 対象領域へ正し く収束する.このように, 当てはめ元および当てはめ先の輝度 值分布が異なるいくつかの状況への対応が期待できることから， 本論文では指標SI を提案した。

\section{2 最適化計算による位置姿勢同定と評価指標の定式化}

$\Sigma_{W}$ に扔ける $\Sigma_{B}$ の初期位置姿勢を $\mathbf{T}_{\mathbf{I}}, \mathbf{T}_{\mathbf{I}}$ 座標系に扔ける ローカル変換を $\mathrm{T}_{\mathbf{L}}$ とすると， $\Sigma_{W} に$ に拈る $\Sigma_{B}$ の位置姿勢 $\mathbf{T}$ は, $\mathrm{T}=\mathrm{T}_{\mathbf{I}} \cdot \mathrm{T}_{\mathrm{L}}$ となる $(\mathrm{Fig} .10) . \mathrm{T}_{\mathrm{L}}$ は， $\mathrm{T}_{\mathbf{I}}$ 座標系におけ る平行移動 $\left(t_{x}, t_{y}, t_{z}\right)$ と, 各軸周りの回転角度 $\left(\theta_{x}, \theta_{y}, \theta_{z}\right)$ の 
6 変数によって計算される。オペレータのインタラクティブな 操作により，目標に十分近い初期位置姿勢から探索を開始でき るため，探索には，比較的所要時間の短い準ニュートン法 [16] を用いる。評価関数の勾配は，現在位置から平行移動と回転移 動を微小量（平行移動の場合は 0.01 [voxel] , 回転移動の場合は 0.01 [deg.] 行ったときの評価関数值から差分方程式を用いて計 算する，最大繰り返し回数を 200 回とする.

ここで評価指標を定式化する。モデルを作成した画像でモ デル内部に含まれる位置座標（有限個）の集合を $\mathbf{X}=\{\mathbf{x}\}$ と し, $\mathbf{X}$ を剛体変換したものを $\mathbf{X}_{\mathbf{t}}=\left\{\mathbf{x}_{\mathbf{t}}: \mathbf{x}_{\mathbf{t}}=\mathbf{T}(\mathbf{x})\right\}$ と表す (Fig. 11)。 $\mathbf{x}$ におけるモデル作成画像の輝度值を $f(\mathbf{x}), \mathbf{x}_{\mathbf{t}}$ に おける位置合わせ対象画像の輝度值を $g\left(\mathbf{x}_{\mathbf{t}}\right)$ とし, $f(\mathbf{x})$ の集合 を $F, g\left(\mathbf{x}_{\mathbf{t}}\right)$ の集合を $G$ とする.

$$
\begin{aligned}
S A D(F, G)= & -\sum_{\mathbf{x} \in \mathbf{X} \cdot \mathbf{x}_{\mathbf{t}} \in \mathbf{x}_{\mathbf{t}}}\left|f(\mathbf{x})-g\left(\mathbf{x}_{\mathbf{t}}\right)\right| \\
N C C(F, G)=- & \frac{\operatorname{Cov}(F, G)}{\sqrt{\operatorname{Var}(F)} \sqrt{\operatorname{Var}(G)}} \\
& (\operatorname{Cov}(X, Y): X \text { とYの共分散, } \\
& \operatorname{Var}(X): X \text { の分散 }) \\
S I(G)= & -\sum_{\mathbf{x}_{\mathbf{t}} \in \mathbf{X}_{\mathbf{t}}} g\left(\mathbf{x}_{\mathbf{t}}\right)
\end{aligned}
$$

SAD およびNCC の計算のため, 骨モデル作成元の MR 画像 の輝度值情報を参照する。また，輝度值は本来ボクセルごとに 離散的に得られる值であるが, 線形補間により任意の位置座標 $\mathbf{x}, \mathbf{x}_{\mathbf{t}}$ に扔ける輝度值 $f(\mathbf{x}), g\left(\mathbf{x}_{\mathbf{t}}\right)$ を算出する。評価関数を計 算するためのメッシュモデル内部に含まれる位置座標の集合 $\mathbf{X}$ は，骨モデル座標系の定義に用いた OBB を，0.5[voxel]（=

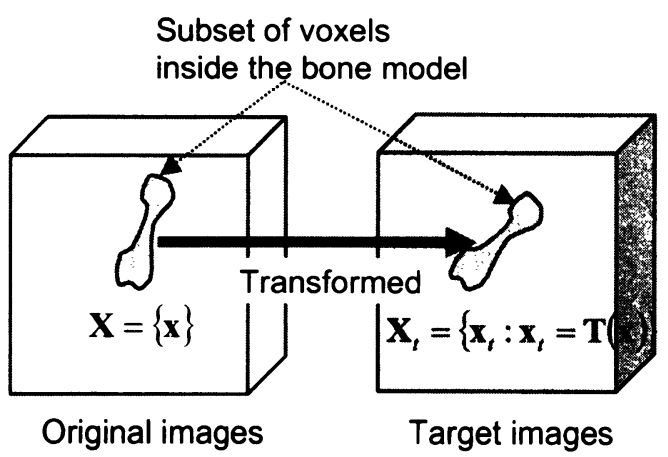

Fig. 11 The subset of voxels inside the bone model (original and transformed)

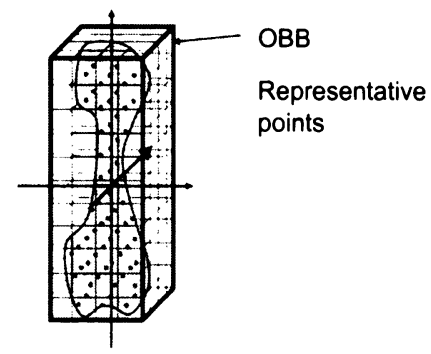

Fig. 12 Representative points defined by OBB division $0.49[\mathrm{~mm}]$ ）間隔で等分割したとき骨モデル内部に存在する格子 点の集合とする (Fig. 12).

\section{3 評価関数の比較実験}

前述の三つの評価関数を用いて，実際の MR 画像から手骨位 置姿勢を同定し，「初期位置姿勢に対するロバストネス」「収束 の正確さ」の二つの観点から，手骨位置姿勢同定に適した評価 関数の比較・検討を行う. 被験者 $\mathrm{A}$ の基準姿勢の MR 画像から 手作業で作成した骨モデルを用い, 姿勢 1 と姿勢 2 の MR 画像 に扔ける手骨（bone No.4－6）の位置姿勢を同定する（Fig. 3）.

3.3 .1 初期位置姿勢に対するロバストネス

オペレータが目視確認しながら，ボリュームレンダリングさ れた MR 画像上の同定対象骨に重なるように骨モデルの初期位 置姿勢を設定する際，正確に重权ようとするほど負担が大きく なることから，骨モデルが正確に収束しうる初期位置姿勢の範 囲は広いほうがよい。そこで, 目標精度を満たす正しい位置姿 勢に収束する確率を見ることで，初期位置姿勢の範囲を評価関 数ごとに比較する。 その際, 初期位置姿勢は, オペレータが最 大限努力して設定しうる骨モデルの位置姿勢精度（Fig. 13, 平 行移動ず社量 $1.4[\mathrm{~mm}]$ 以内，回転ずれ量 10 [deg.] 以内）を参 考に，それより広い範囲となるよう与える。具体的には，初期 位置姿勢として, 真值からの平行移動ず扎量 $1,2,3,4[\mathrm{~mm}]$, 回転ずれ量 10，15，20 [deg.] の組み合わせからランダムに 20 パターン選択して設定し，目標精度を満たす位置姿勢に収束す る確摔を求めた。Fig. 14 は, 示指末節骨（bone No.7）の場合 の，オペレータのインタラクティブな設定による初期位置姿勢 の最大誤差と, 収束性評価で与えた初期位置姿勢の最大誤差の

一例を，真值の骨位置姿勢座標系で示したものである．分かり やすさのため, どちらも，真值の骨座標系の $\mathrm{x}$ 軸に沿ったべク トル $(1 ， 0 ， 0)$ の向きの並進ずれを起こしている場合とし，回 転については同 $\mathrm{y}$ 軸（ベクトル $(0,1 ， 0))$ 周りに回転ずれを 起こしている状態を想定した図となっている.

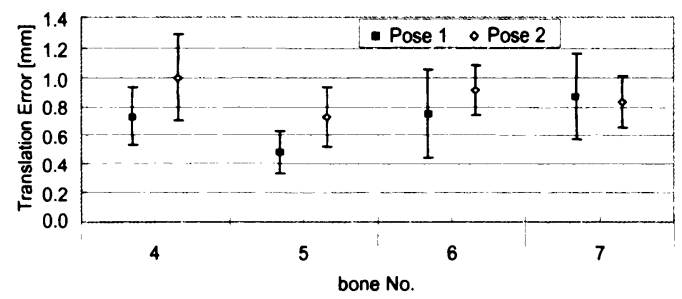

(a) Translation error

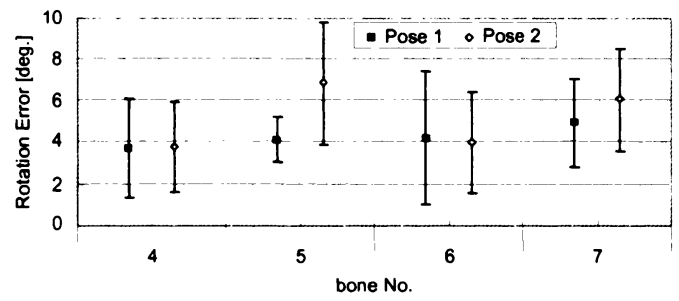

(b) Rotation error

Fig. 13 Accuracy of the interactive initial configuration settlement by the operator with a best effort (mean \pm std. dev. of five trials) 
Table 3 The percentage of convergence to correct configuration using three performance indices. Each percentage more than $90 \%$ is enclosed with a rectangle

(a) Pose 1

\begin{tabular}{|c|c|c|c|c|c|c|c|c|c|c|c|c|c|}
\hline \multirow[b]{3}{*}{ Measure } & \multirow[b]{3}{*}{ Bone No. } & \multicolumn{12}{|c|}{ Initial misregistration } \\
\hline & & \multicolumn{3}{|c|}{$1 \mathrm{~mm}$} & \multicolumn{3}{|c|}{$2 \mathrm{~mm}$} & \multicolumn{3}{|c|}{$3 \mathrm{~mm}$} & \multicolumn{3}{|c|}{$4 \mathrm{~mm}$} \\
\hline & & $10^{\circ}$ & $15^{\circ}$ & $20^{\circ}$ & $10^{\circ}$ & $15^{\circ}$ & $20^{\circ}$ & $10^{\circ}$ & $15^{\circ}$ & $20^{\circ}$ & $10^{\circ}$ & $15^{\circ}$ & $20^{\circ}$ \\
\hline \multirow[t]{4}{*}{ SAD } & 4 & $100 \%$ & $100 \%$ & $60 \%$ & $100 \%$ & $100 \%$ & $95 \%$ & $100 \%$ & $90 \%$ & $30 \%$ & $95 \%$ & $30 \%$ & $65 \%$ \\
\hline & 5 & $100 \%$ & $100 \%$ & $95 \%$ & $100 \%$ & $90 \%$ & $100 \%$ & $70 \%$ & $65 \%$ & $80 \%$ & $75 \%$ & $80 \%$ & $65 \%$ \\
\hline & 6 & $100 \%$ & $100 \%$ & $100 \%$ & $100 \%$ & $95 \%$ & $95 \%$ & $90 \%$ & $100 \%$ & $90 \%$ & $95 \%$ & $70 \%$ & $95 \%$ \\
\hline & 7 & $100 \%$ & $100 \%$ & $100 \%$ & $100 \%$ & $100 \%$ & $75 \%$ & $100 \%$ & $100 \%$ & $100 \%$ & $70 \%$ & $75 \%$ & $70 \%$ \\
\hline \multirow[t]{4}{*}{ NCC } & 4 & $95 \%$ & $100 \%$ & $35 \%$ & $100 \%$ & $85 \%$ & $70 \%$ & $95 \%$ & $80 \%$ & $35 \%$ & $95 \%$ & $40 \%$ & $50 \%$ \\
\hline & 5 & $80 \%$ & $95 \%$ & $25 \%$ & $20 \%$ & $40 \%$ & $40 \%$ & $80 \%$ & $55 \%$ & $15 \%$ & $65 \%$ & $75 \%$ & $65 \%$ \\
\hline & 6 & $100 \%$ & $100 \%$ & $100 \%$ & $100 \%$ & $100 \%$ & $55 \%$ & $100 \%$ & $90 \%$ & $85 \%$ & $80 \%$ & $60 \%$ & $5 \%$ \\
\hline & 7 & $100 \%$ & $95 \%$ & $90 \%$ & $50 \%$ & $55 \%$ & $45 \%$ & $25 \%$ & $25 \%$ & $5 \%$ & $10 \%$ & $0 \%$ & $15 \%$ \\
\hline \multirow[t]{4}{*}{ SI } & 4 & $100 \%$ & $100 \%$ & $70 \%$ & $100 \%$ & $100 \%$ & $90 \%$ & $100 \%$ & $90 \%$ & $70 \%$ & $70 \%$ & $85 \%$ & $85 \%$ \\
\hline & 5 & $100 \%$ & $100 \%$ & $95 \%$ & $100 \%$ & $100 \%$ & $90 \%$ & $100 \%$ & $100 \%$ & $90 \%$ & $90 \%$ & $100 \%$ & $100 \%$ \\
\hline & 6 & $100 \%$ & $100 \%$ & $100 \%$ & $100 \%$ & $100 \%$ & $100 \%$ & $100 \%$ & $100 \%$ & $100 \%$ & $100 \%$ & $100 \%$ & $95 \%$ \\
\hline & 7 & $100 \%$ & $100 \%$ & $95 \%$ & $100 \%$ & $100 \%$ & $95 \%$ & $100 \%$ & $100 \%$ & $95 \%$ & $95 \%$ & $95 \%$ & $90 \%$ \\
\hline
\end{tabular}

(b) Pose 2

\begin{tabular}{|c|c|c|c|c|c|c|c|c|c|c|c|c|c|}
\hline \multirow[b]{3}{*}{ Measure } & \multirow[b]{3}{*}{ Bone No. } & \multicolumn{12}{|c|}{ Initial misregistration } \\
\hline & & \multicolumn{3}{|c|}{$1 \mathrm{~mm}$} & \multicolumn{3}{|c|}{$2 \mathrm{~mm}$} & \multicolumn{3}{|c|}{$3 \mathrm{~mm}$} & \multicolumn{3}{|c|}{$4 \mathrm{~mm}$} \\
\hline & & $10^{\circ}$ & $15^{\circ}$ & $20^{\circ}$ & $10^{\circ}$ & $15^{\circ}$ & $20^{\circ}$ & $10^{\circ}$ & $15^{\circ}$ & $20^{\circ}$ & $10^{\circ}$ & $15^{\circ}$ & $20^{\circ}$ \\
\hline \multirow[t]{4}{*}{ SAD } & 4 & $100 \%$ & $100 \%$ & $45 \%$ & $100 \%$ & $70 \%$ & $20 \%$ & $100 \%$ & $70 \%$ & $25 \%$ & $100 \%$ & $85 \%$ & $25 \%$ \\
\hline & 5 & $100 \%$ & $95 \%$ & $35 \%$ & $75 \%$ & $70 \%$ & $70 \%$ & $75 \%$ & $40 \%$ & $10 \%$ & $5 \%$ & $25 \%$ & $0 \%$ \\
\hline & 6 & $100 \%$ & $95 \%$ & $15 \%$ & $20 \%$ & $0 \%$ & $10 \%$ & $5 \%$ & $5 \%$ & $0 \%$ & $0 \%$ & $10 \%$ & $0 \%$ \\
\hline & 7 & $100 \%$ & $95 \%$ & $95 \%$ & $95 \%$ & $100 \%$ & $90 \%$ & $55 \%$ & $40 \%$ & $30 \%$ & $0 \%$ & $0 \%$ & $0 \%$ \\
\hline \multirow[t]{4}{*}{ NCC } & 4 & $100 \%$ & $100 \%$ & $50 \%$ & $100 \%$ & $90 \%$ & $45 \%$ & $100 \%$ & $90 \%$ & $40 \%$ & $100 \%$ & $90 \%$ & $40 \%$ \\
\hline & 5 & $95 \%$ & $90 \%$ & $30 \%$ & $100 \%$ & $95 \%$ & $65 \%$ & $95 \%$ & $75 \%$ & $35 \%$ & $85 \%$ & $60 \%$ & $60 \%$ \\
\hline & 6 & $100 \%$ & $100 \%$ & $50 \%$ & $90 \%$ & $20 \%$ & $60 \%$ & $55 \%$ & $35 \%$ & $10 \%$ & $50 \%$ & $45 \%$ & $30 \%$ \\
\hline & 7 & $100 \%$ & $95 \%$ & $100 \%$ & $80 \%$ & $75 \%$ & $65 \%$ & $60 \%$ & $65 \%$ & $30 \%$ & $25 \%$ & $15 \%$ & $10 \%$ \\
\hline \multirow[t]{4}{*}{$\overline{\text { SI }}$} & 4 & $100 \%$ & $100 \%$ & $85 \%$ & $100 \%$ & $100 \%$ & $50 \%$ & $100 \%$ & $100 \%$ & $60 \%$ & $100 \%$ & $100 \%$ & $90 \%$ \\
\hline & 5 & $100 \%$ & $100 \%$ & $20 \%$ & $100 \%$ & $45 \%$ & $60 \%$ & $100 \%$ & $55 \%$ & $40 \%$ & $90 \%$ & $80 \%$ & $25 \%$ \\
\hline & 6 & $100 \%$ & $100 \%$ & $100 \%$ & $100 \%$ & $95 \%$ & $100 \%$ & $100 \%$ & $95 \%$ & $40 \%$ & $50 \%$ & $50 \%$ & $40 \%$ \\
\hline & 7 & $100 \%$ & $100 \%$ & $100 \%$ & $100 \%$ & $100 \%$ & $100 \%$ & $100 \%$ & $100 \%$ & $100 \%$ & $100 \%$ & $95 \%$ & $95 \%$ \\
\hline
\end{tabular}

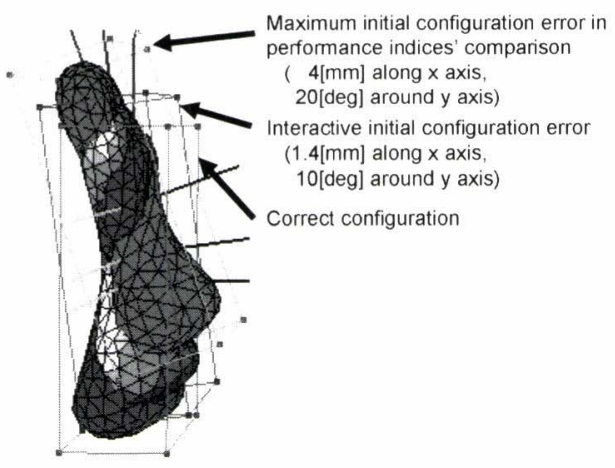

Fig. 14 Example of initial configuration errors (Interactive settlement error and the maximum error given in the performance indices' comparison)

各評価指標を用いた場合に目標精度を満たす位置姿勢に収束 する確率を Table 3 にまとめる。表中では，90\%以上の確率の 部分を四角で囲んで示してある. 同表より，正しく収束する確率 が広範囲にわたって高いのは評価関数 SI であり, 計算を行った すべての手骨（bone No.4〜6）が90\%以上の確率で収束した初 期位置姿勢の範囲は, 姿勢 1 では $3[\mathrm{~mm}]$ 以内かつ $15[\mathrm{deg}$.$] 以$ 内, 姿勢 2 では $3[\mathrm{~mm}]$ 以内かつ $10[\mathrm{deg}]$ 以内の場合であった.

モデルを作成した画像の輝度值と，位置合わせ対象画像の輝 度值との類似度を計る評価関数 SAD と NCCのロバストネス が, 位置合わせ対象画像の輝度值のみを用いた評価関数 SI より も低かったのは，手の骨の大きさに対して MR 画像の解像度が 低く，異なる姿勢の画像では同一被験者の同一の骨であっても 輝度值分布が正確には一致しないことの影響が大きかったため と考えられる。

ただし，評価関数 SI を用いても，掌に含まれる中手骨（bone
Table 4 Mean and standard deviation of identified configurationsal misregistration of $1[\mathrm{~mm}]$ and 10 [deg.]

\begin{tabular}{|c|c|c|c|c|c|}
\hline Measure & Bone No. & \multicolumn{2}{|c|}{\begin{tabular}{rr}
\multicolumn{2}{|c}{ Pose 1} \\
Trans. error & Rot. error \\
{$[\mathrm{mm}]$} & [deg.]
\end{tabular}} & $\begin{array}{r}\text { Pos } \\
\text { Trans. error } \\
{[\mathrm{mm}]}\end{array}$ & $\begin{array}{l}2 \\
\text { Rot. error } \\
\text { [deg.] }\end{array}$ \\
\hline \multirow[t]{4}{*}{$\mathrm{SAD}$} & 4 & $0.16(0.00)$ & $0.7(0.0)$ & $0.08(0.00)$ & $1.8(0.0)$ \\
\hline & 5 & $0.20(0.00)$ & $1.1(0.0)$ & $0.13(0.00)$ & $2.0(0.0)$ \\
\hline & 6 & $0.49(0.00)$ & $1.0(0.0)$ & $0.31(0.00)$ & $1.9(0.0)$ \\
\hline & 7 & $0.41(0.00)$ & $2.1(0.1)$ & $0.43(0.00)$ & $2.9(0.1)$ \\
\hline \multirow[t]{4}{*}{$\mathrm{NCC}$} & 4 & $0.11(0.00)$ & $0.6(0.0)$ & $0.09(0.00)$ & $1.7(0.0)$ \\
\hline & 5 & $0.21(0.05)$ & $1.3(0.9)$ & $0.14(0.02)$ & $2.0(0.5)$ \\
\hline & 6 & $0.50(0.00)$ & $0.7(0.0)$ & $0.30(0.00)$ & $2.0(0.0)$ \\
\hline & 7 & $0.44(0.01)$ & $1.8(0.1)$ & $0.47(0.00)$ & $2.3(0.1)$ \\
\hline \multirow[t]{4}{*}{ SI } & 4 & $0.09(0.00)$ & $0.7(0.1)$ & $0.23(0.00)$ & $3.4(0.0)$ \\
\hline & 5 & $0.23(0.01)$ & $1.3(0.1)$ & $0.37(0.00)$ & $2.2(0.1)$ \\
\hline & 6 & $0.29(0.00)$ & $1.3(0.1)$ & $0.28(0.01)$ & $1.9(0.1)$ \\
\hline & 7 & $0.12(0.01)$ & $3.0(0.5)$ & $0.43(0.01)$ & $2.1(0.2)$ \\
\hline
\end{tabular}

No.4）の平行移動ずれ量 $4[\mathrm{~mm}]$ 以上での収束確率が低かった のは，隣の骨との距離が近く，初期位置姿勢で他の骨に多くの 領域が重なる確率が高かったためであり，他の骨と多く重なる ような初期位置姿勢は避ける必要がある。

\section{3.2 収束の正確さ}

Table 4 は，ずれ量が $1[\mathrm{~mm}] \cdot 10$ [deg.] の組み合わせの初 期位置姿勢からすべての評価関数で正しい位置姿勢に収束した 結果について, 平行移動ずれ量, 回転ずれ量それぞれの平均值 と標準偏差を示す。

収束結果の正確さについては，評価関数による差はあまり見 ら机なかった。初期值に対するロバストネスの最も高かった SI について見ると，平行移動ずれ量は $0.4[\mathrm{~mm}]$ 以内，回転ずれ 量は 4 [deg.] 以内に収まっており，目標精度（平行移動ずれ量 $0.6[\mathrm{~mm}]$ 以内, 回転ずれ量 8 [deg.] 以内）を十分に満たしてい 
る. 標準偏差は, $0.02[\mathrm{~mm}]$ 以内, $0.6[\mathrm{deg}$.$] 以内と小さく, 安$ 定して正確な位置姿勢に収束している。

以上，初期位置姿勢に対するロバストネス，収束の正確さの観 点から, 三つの評価関数のうち, SI が最もロバストな評価関数 であり，収束結果も安定した正確なものであることが分かった。

\section{4. 提案システムの妥当性の総合検証実験}

\section{1 実験概要}

前章で有効性を示した評価関数 SI 用い, 提案システムが, すべての姿勢の画像から手骨のメッシュモデルを手作業で作成 して位置姿勢を同定する手法と比較して, 同等の精度, および, 短い時間で手骨位置姿勢を求められることを確認する。

本実験では，手全体の骨 19 個を対象とし，骨による結果の 違いを検証する。また, 計 3 名の被験者 $\mathrm{A}, \mathrm{B}, \mathrm{C}$ を対象とし, 被験者による違いを検証する，前章の実験と同様に，同一被験 者の基準姿勢の MR 画像から手作業で作成した骨モデルを用い て, 姿勢 1 と姿勢 2 に抒ける手骨の位置姿勢を同定する，同定 実験は姿勢 1 , 姿勢 2 の画像に対して各 5 回行った。その他の 実験条件は同じである。

\section{2 実験結果と考察}

\subsection{1 収束結果}

被験者 A，B，Cの同定結果の目標モデルからのずれを Fig. 15 に示す. 図中の点線は, 目標精度である $0.6[\mathrm{~mm}]$ と $8[\mathrm{deg}$.] を 示している. 3 名の被験者の姿勢 1 , 姿勢 2 の両方に拀いて，ほ とんどの骨が平行移動ずれ量, 回転ずれ量共に目標精度を満た しているが, 被験者 $\mathrm{C}$ の骨 7 と 11 に関しては, ずれ量が大き い. 骨 7 と 11 は末節骨であり，これらの骨の大きさに対して MR 画像の解像度が低いために, 骨モデルの形状がそもそも不 正確だった，あるいは，異なる姿勢の画像では同一の骨であっ ても輝度值分布が正確には一致しないことの影響が大きかった ことが原因と考えられる。

よって, 被験者によっては末節骨について当てはまらないこ ともあるが，オペレータによりインタラクティブに設定された 初期位置姿勢から，最適化計算による位置合わせによって，骨 モデルは目標精度を満たす正しい位置姿勢に収束することが示 された。

\subsection{2 所要時間}

初期位置姿勢の設定に要した時間は，一姿勢分 19 個当たり お扰よそ 20 分程度であった。被験者 $\mathrm{A}$ の姿勢 1 の収束計算に 要した時間を Fig. 16 に示す。一姿勢分 19 個の骨の計算には おおよそ5分を要した。

ここで, 文献 [1] と同様のケース，すなわち同一被験者の異な る四つの姿勢の MR 画像から手骨の位置姿勢を求めるのに要す る時間の試算により，すべて手作業でメッシュモデルを作成し 各骨の位置姿勢を求める手法と比較する（Table 5)，まず手作 業で骨領域を抽出してメッシュモデルを作成する場合，一つの 姿勢あたり約 3 時間, 4 姿勢の画像では 12 時間を要する。本手 法では，骨モデル作成に 3 時間，他の三つの画像に対し骨モデ ルの位置合わせを行うのに初期位置姿勢の設定 $(20$ 分 $\times 3)$ お よび計算 $(5$ 分 $\times 3)$ で 75 分必要である. したがって，すべての 画像から手作業でメッシュモデルを作成するのに比べて，骨モ

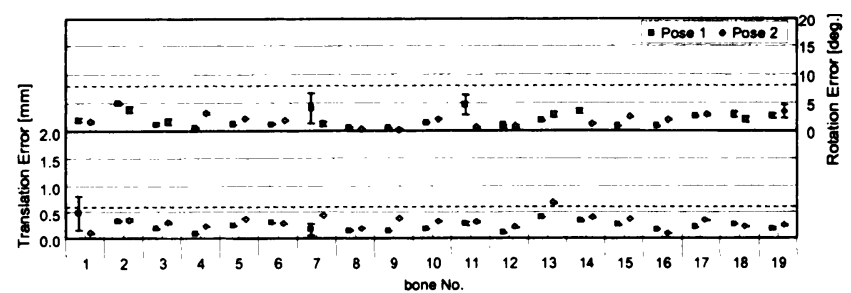

(a) subject $A$

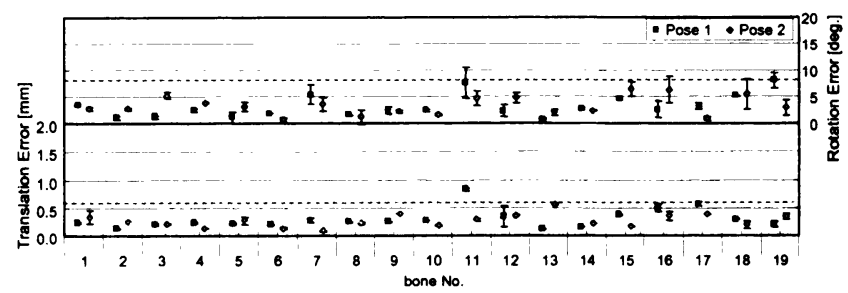

(b) subject $B$

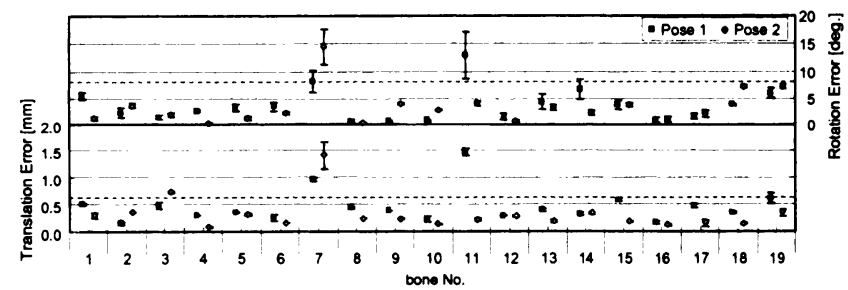

(c) subject $\mathrm{C}$

Fig. 15 Error of identified configuration for subject A, B, and $\mathrm{C}$ (mean \pm std. dev. of 5 trial)

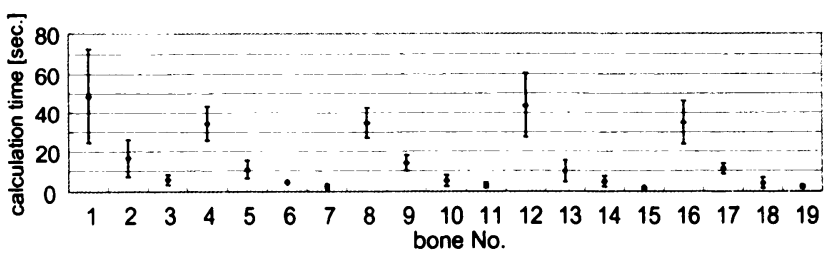

Fig. 16 Calculation time for pose 1 of subject $A$

Table 5 Comparison of time required to process 4 pose images

\begin{tabular}{l|r|r||r||r|r}
\hline \hline & \multicolumn{3}{|c|}{ Manual operation time[min.] } & $\begin{array}{r}\text { Calculation } \\
\text { time[min.] }\end{array}$ & $\begin{array}{c}\text { Total } \\
{[\text { min.] }}\end{array}$ \\
\cline { 2 - 5 } & Making model & Initialization & Sum & & \\
\hline $\begin{array}{l}\text { Manual } \\
\text { segmentation }\end{array}$ & $180 \times 4$ & & 720 & - & 720 \\
\hline $\begin{array}{l}\text { Proposed } \\
\text { system }\end{array}$ & $180 \times 1$ & $20 \times 3$ & 240 & $5 \times 3$ & 255 \\
\hline \hline
\end{tabular}

デル作成を含めオペレータによるインタラクティブな作業にか かる時間は, 12 時問から 4 時間, すなわち 3 分の 1 まで短縮す ることができる. 計算時間を含めて考えても 12 時間から 4 時間 15 分で，やはり扰扰よそ 3 分の 1 にまで短縮することになる。

\section{5.おわりに}

本稿では，同一被験者の異なる手姿勢の MR 画像から手骨位 置姿勢を求める際に，すべて手作業で骨領域を抽出する場合と 比べて, 同等の精度（平行移動ずれ量 $0.6[\mathrm{~mm}]$ 以内, 回転ずれ 量 8 [deg.] 以内）を保ちつつ所要時間を短縮する省力化システ ムを実装した，MR 画像の一つから手作業による手骨領域抽出 
で骨モデルを作成し，残りの姿勢の画像については，骨モデル の初期位置姿勢をオペレータがインタラクティブに指定したう えで, 評価関数の最適化計算によって骨モデルの位置合わせを 自動的に行った。

最適化計算に用いる評価関数として，代表的な関数である $\mathrm{SAD}, \mathrm{NCC}$ と, 独自の評価関数 SI (骨モデル内部の輝度值和) を比較する実験を行った。その結果, SI が最も初期位置姿勢に ロバストな評価関数であり, 収束結果も安定した正確なもので あることを示した。そこで，インタラクティブに設定した初期 位置姿勢から評価関数 SI を用いて同定実験を行った結果, 手作 業抽出によって手骨のメッシュモデルを作成する手法と同等の 精度で手骨位置姿勢を同定することができた。さらに，4 姿勢 分の画像を処理する場合には約 3 分の 1 にまで所要時間を短縮 することを示し，提案システムの有効性を証明した。

本稿で提案した手法は, 被験者ごとに骨モデルを作成する必 要があるため, 複数の被験者のデー夕を処理する場合には, 骨 モデルを被験者の数だけ作成しなければならず, やはり作業時 間が長い、筆者らの予備実験により，手骨形状の個人差はあま り大きくないことが分かっており, 今後の展望として, 一般的 な形状の骨モデルを用いて任意の被験者の画像に扔ける手骨位 置姿勢を同定する手法への拡張が考えられる.

\section{参 考 文 献}

[1] N. Miyata et al.: "Finger Joint Kinematics from MR Images," Proceedings of the 2005 IEEE/RSJ International Conference on Intelligent Robots and Systems, pp.4110-4115, 2005.

[2] J.H. Ryu et al.: "Analysis of skin movement with respect to flexional bone motion using MR images of a hand," Journal of Biomechanics, vol.39, no.5, pp.844-852, 2006.

[3] M. Kass et al.: "Snakes: Active Contour Models," International Journal of Computer Vision, vol.1, no.4, pp.321-331, 1987.

[4] L.D. Cohen and I. Cohen: "Finite Element Methods for Active Contour Models and Balloons for 2D and 3D Images," IEEE Transactions on pattern analysis and Machine Intelligence, vol.15, no.11, pp.1131-1147, 1993.

[5] T.B. Sebastian et al.: "Segmentation of Carpal Bones from CT Images Using Skeletally Coupled Deformable Models," Medical Image Analysis, vol.7, pp.21-45, 2003.
[6] B. Tsagaanet et al.: "An Automated Segmentation Method of Kidney Using Statistical Information," MICCAI, LNCS 2488, pp.556-563, 2002.

[7] ツァガーンバイガルマ他：“三次元可変形状モデルによる腹部 CT 像か らの腎臓領域抽出法の開発”, 電子情報通信学会論文誌 D-I, vol.J85D-II, no.1, pp.140-148, 2002.

[8] L.M. Lorigo et al.: "Segmentation of Bone in Clinical Knee MRI Using Texture-Based Geodesic Active Contours," MICCAI, pp.1195-1204, 1998.

[9] G. Szekely et al.: "Segmentation of 2-d and 3-d objects from MRI volume data using constrained elastic deformations of flexible Fourier contour and surface models," Medical Image Analysis, vol.1, no.1, pp.19-34, 1996.

[10] B. Gilles et al.: "Bone motion analysis from dynamic MRI: acquisition and tracking," MICCAI, 2004.

[11] W. Lorensen and H. Cline: "Marching Cubes: A High Resolution 3D Surface Construction Algorithm," Computer Graphics, vol.21, no.4, pp.163-169, 1987.

[12] R.A. Drebin et al.: "Volume rendering," Proceedings of the 15 th annual conference on Computer graphics and interactive techniques, pp.65-74, 1988.

[13] S. Gottschalk et al.: "OBB-Tree: A Hierarchical Structure for Rapid Interference Detection," Proceedings of ACM SIGGRAPH, pp.171-180, 1996.

[14] UNC Research Group on Modeling, Physically-Based Simulation and Applications: RAPID - Robust and Accurate Polygon Interference Detection, http://www.cs.unc.edu/geom/OBB/ OBBT.html

[15] P.J. Besl and N.D. McKay: "A Method for Registration of 3-D Shapes," IEEE Transactions on Pattern Analysis and Machine Intelligence, vol.14, no.2, pp.239-256, 1992.

[16] W.H. Press et al.: Numerical Recipes in C++. pp.430-434, Cambridge University Press, 1992.

[17] M. Holden et al.: "Voxel Similarity Measures for 3D Serial MR Brain Image Registration," IEEE Transactions on Medical Imaging, vol.19, no.2, pp.472-477, 2000.

[18] C. Studholme and D.L.G. Hill: "Automated ThreeDimensional Registration of Magnetic Resonance and Positron Emission Tomography Brain Images by Multiresolution Optimisation of Voxel Similarity Measures," Medical Physics, vol.24, no.1, pp.25-35, 1997.

[19] A. Roche et al.: "Unifying Maximum Likelihood Approaches in Medical Image Registration," International Journal of Imaging Systems and Technology: Special Issue on 3D Imaging, vol.11, no.11, pp.71-80, 2000.

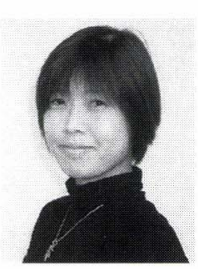

宮田なつき（Natsuki Miyata）

1972 年 5 月 18 日生. 2000 年東京大学大学院工学 系研究科精密機械工学専攻修了, 博士 (工学). 同 年工業技術院機械技術研究所入所, 2001 年より現 職. 人体, 特に手の構造と運動のモデル化に関する 研究に従事.

(日本ロボット学会正会員)

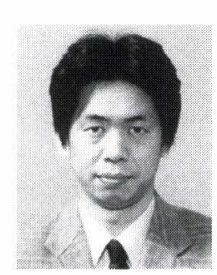

太田 順 (Jun Ota)

1965 年 2 月 19 日生. 1989 年東京大学大学院工学系 研究科精密機械工学専攻修上課程修了. 同年新日本 製鐵（株）入社. 1991 年東京大学工学部助于. 1994 年同講師. 1996 年より東京大学大学院工学系研究 科精密機械工学専攻助教授. この間 1996 1997 年 Stanford 大学 Center for Design Research 客員研 究員, 群知能ロボットと移動知, 大規模生産/搬送システム, ヒュー マンアナリシス等の研究に従事. 博上 (工学).

(日本ロボット学会正会員)
鴨島里実 (Satomi Kamojima)

1981 年 3 月 11 日生. 2003 年東京大学工学部シス テ么創成学科卒業, 2005 年同大学大学院工学系研 究科精密機械工学専攻修了. MR 画像からの手骨 位置姿勢同定理論の研究に従事. 現在，新日鉄y リューションズ (株) に勤務. 